Brit. Heart F., 1966, 28, 602.

\title{
Rheumatoid Pericarditis with Cardiac Failure Treated by Pericardiectomy
}

\author{
W. P. U. KENNEDY, R. E. H. PARTRIDGE, AND MICHAEL B. MATTHEWS
}

\author{
From the Western and Northern General Hospitals, Edinburgh, and the Department of Medicine, University \\ of Edinburgh
}

Pericarditis is recognized as a common finding at necropsy in patients with rheumatoid arthritis, but the existence of various clinical syndromes associated with rheumatoid pericarditis is less widely appreciated. Transient acute pericarditis with friction, pericardial effusion, cardiac tamponade, and chronic constrictive pericarditis have all been described. Fifteen patients with chronic rheumatoid arthritis who had undergone pericardiectomy have been reported in the English language at the time of writing. The majority of these benefited from surgical treatment (Table I). The patient described by Szatkowski and Inoue (1963) had rheumatoid arthritis, but his chronic effusive pericarditis was assumed to be of tuberculous origin despite failure to isolate any tubercle bacilli. This paper describes 3 patients with symptomatic rheumatoid pericarditis treated by pericardiectomy. One of these patients (Case 1) has been briefly described in a previous communication (Partridge and Duthie, 1963).

\section{CASE REPORTS}

Case 1. A man aged 49 years, formerly a foundry worker, had experienced transient joint pains at the age of 35 . Five years before he was admitted to hospital he developed a right pleural effusion with opacities in both lung fields, and for more than two years was given antituberculosis chemotherapy in the belief that he had pulmonary tuberculosis, despite repeated failure to culture tubercle bacilli from the sputum. A year later, at 45 , he developed pain in the elbows and shoulders, with spindling of the fingers and subcutaneous nodules at the elbows and wrist. Radiographs showed erosions of the metatarsal heads. After in-patient treatment for rheumatoid arthritis his functional capacity remained

Received August 3, 1965. normal. Bilateral pleural effusions requiring repeated aspiration were by now considered to be due to the rheumatoid disease. At about this time he developed lichen planus on the limbs; this was treated with systemic prednisolone, which was continued for two years. The corticosteroid had little effect on the pleural effusions.

At 49 he was readmitted to hospital, acutely ill, dyspnœic, and cyanosed, with gross œdema of the legs, sacrum, external genitalia, abdominal wall, and forearms. There was pulsus paradoxus with a systolic pressure varying between 90 and $110 \mathrm{~mm}$. $\mathrm{Hg}$. The jugular venous pressure was more than $15 \mathrm{~cm}$. Chest radiographs showed a large cardiac shadow with bilateral pleural effusions (Fig. 1). The cardiothoracic ratio (CTR) was $180 / 300$, or 60 per cent. The electrocardiogram was of low voltage and had flattened $T$ waves. The hæmoglobin was 92 per cent, white cell count 14,050 c.mm., and erythrocyte sedimentation rate (ESR) Westergren $43 \mathrm{~mm}$. in the first hour. Four examinations for lupus erythematosus (LE) cells were negative, and no antinuclear factor was found in the serum. The latex fixation test was positive. Direct examination and culture of sputum and of pleural and pericardial fluids were repeatedly negative for Mycobacterium tuberculosis.

Pericardial aspiration soon after admission yielded $500 \mathrm{ml}$. blood-stained fluid, but was not followed by any visible alteration in his condition, and pulsus paradoxus persisted. He was treated in a cardiac bed with mersalyl. Southey's tubes were inserted, and there was a fall in weight from $165 \mathrm{lb}$. $(75 \mathrm{~kg}$.) to $146 \mathrm{lb}$. (66 kg.), due to loss of œdema fluid, over a period of 6 days. Despite this fluid loss, the venous pressure remained raised. Pericardial aspiration was repeated three weeks later with the withdrawal of $400 \mathrm{ml}$. bloodstained fluid. A radiograph taken after the introduction of $200 \mathrm{ml}$. of air showed loculation within the pericardial sac.

In view of the persisting rise in venous pressure and 602 the demonstration of loculation, it was decided to sub- 
TABLE I

CLINICAL FEATURES OF 15 REPORTED CASES OF CHRONIC RHEUMATOID ARTHRITIS WHO HAVE UNDERGONE PERICARDIECTOMY

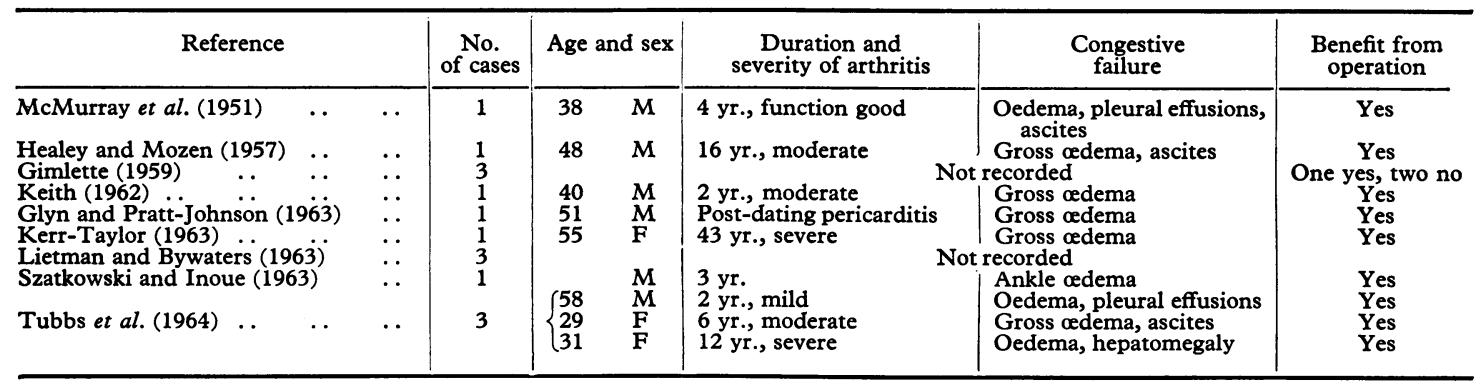

mit the patient to pericardiectomy. Mr. R. J. M. McCormack resected the pericardium and the left parietal pleura 6 weeks after admission. The parietal and visceral pericardium between the two phrenic nerves was removed, freeing the right atrium and both ventricles. A considerable quantity of yellow porridgey material was contained in the pericardial sac, and there was no remaining liquid. The thickness of the parietal pericardium varied from $2 \mathrm{~mm}$. to $1 \mathrm{~cm}$. and that of the visceral layer from $2 \mathrm{~mm}$. to $5 \mathrm{~mm}$. On histological examination there was fibrous thickening of the pericardium with perivascular infiltration by lymphoid and plasma cells. The appearances were those of a nonspecific chronic inflammation.

The congestive cardiac failure resolved after operation, with a further fall in weight to $104 \mathrm{lb}$. (47 kg.). From this point of view the operation was a success.

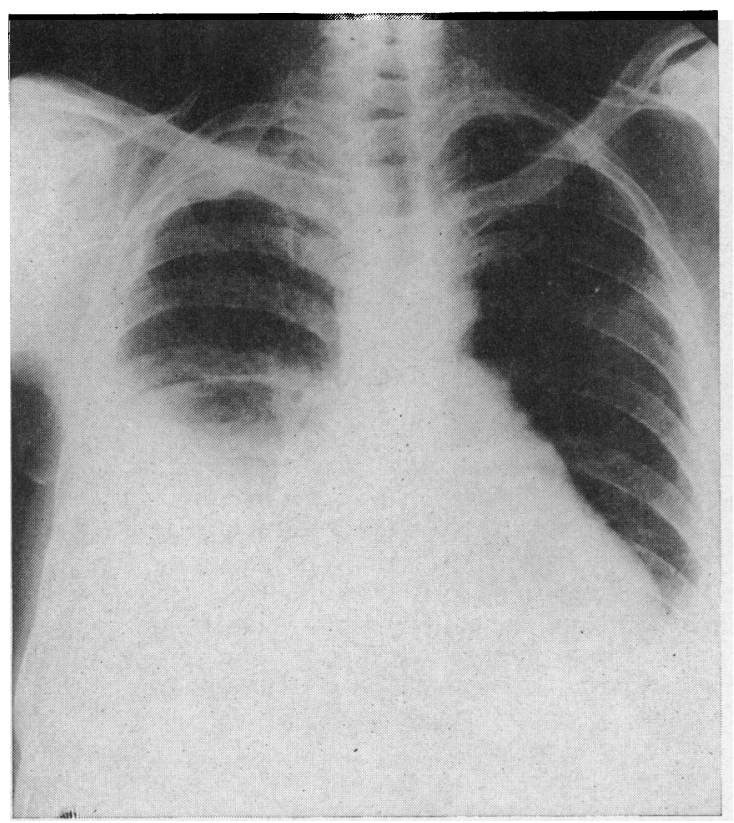

FIG. 1 (Case 1).-Chest radiograph after pericardial aspiration and air insufflation. There is a loculated pericardial effusion, with a fluid level within the cardiac shadow.
Subsequent aspiration of a pleural effusion unfortunately resulted in an empyema which required drainage. Three years after operation the patient was in reasonable health with neither pleural effusion nor heart failure, and now weighed $117 \mathrm{lb}(53 \mathrm{~kg}$.). His joint symptoms were quiescent and he was seeking re-employment.

Case 2. A housewife aged 51 years was admitted following the radiographic demonstration of a pericardial effusion. Rheumatic fever at the ages of 19 and 29 had resulted in mild aortic stenosis and incompetence. At 46 she developed rheumatoid arthritis, and though she continued thereafter to suffer some joint pain on movement her functional capacity remained normal.

Four months before the present investigation she was treated in another hospital for an aspiration pneumonia. At that time there was dyspnœa, cyanosis, dependent œdema, and a raised venous pressure. The congestive failure responded to medical treatment, but there was persistent radiographic evidence of a pericardial effusion. Four specimens of sputum were negative on culture for Myco. tuberculosis.

At the time of admission the venous pressure was normal. Arterial pressure was $140 / 80 \mathrm{~mm}$. $\mathrm{Hg}$, and pulsus paradoxus was not present. The apex beat was impalpable, but the heart sounds were clearly audible. There was a grade $2 / 6$ aortic systolic ejection murmur propagated to the apex, a grade $2 / 6$ early diastolic murmur at the left sternal edge, and a third heart sound at the apex. The chest radiograph showed gross enlargement of the heart shadow, with a CTR of 240/270 or 89 per cent (Fig. 2). No cardiac movements were detected on fluoroscopy. The cardiogram was of normal voltage with $T$ inversion in leads $I, I I$, and V4 to V6. Her fingers were moderately spindled with ulnar deviation at the metacarpo-phalangeal joints. The wrists, elbows, and knees were painful on movement. Erosive changes were seen in several joints in radiographs of both hands and feet. The hæmoglobin was 83 per cent and the ESR $50 \mathrm{~mm}$. in the first hour. The latex test was positive and the sensitized sheep cell test (SSCT) gave a titre of 1:256. Antinuclear factor was not detected, and there were no LE cells on five examinations. Pericardial paracentesis yielded $500 \mathrm{ml}$. 


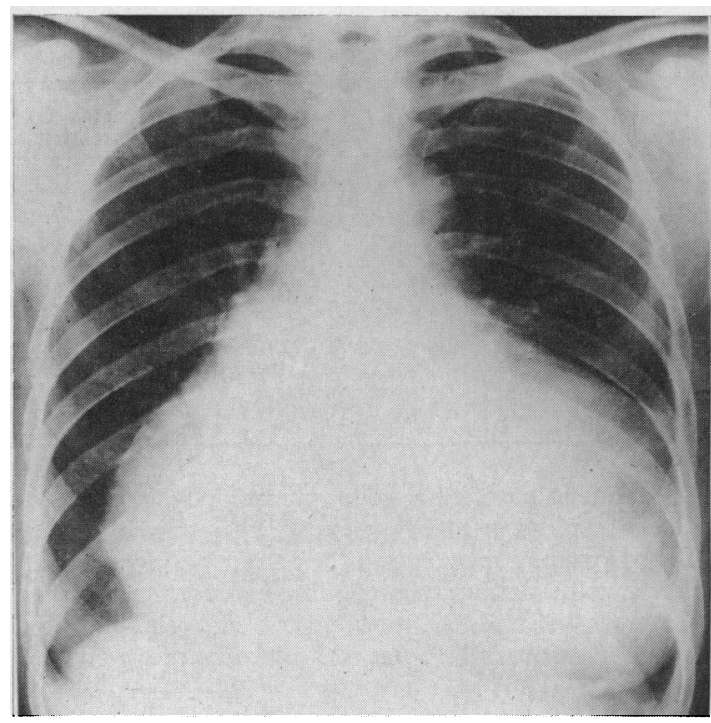

A

FIG. 2.-Radiographs of Cas 2

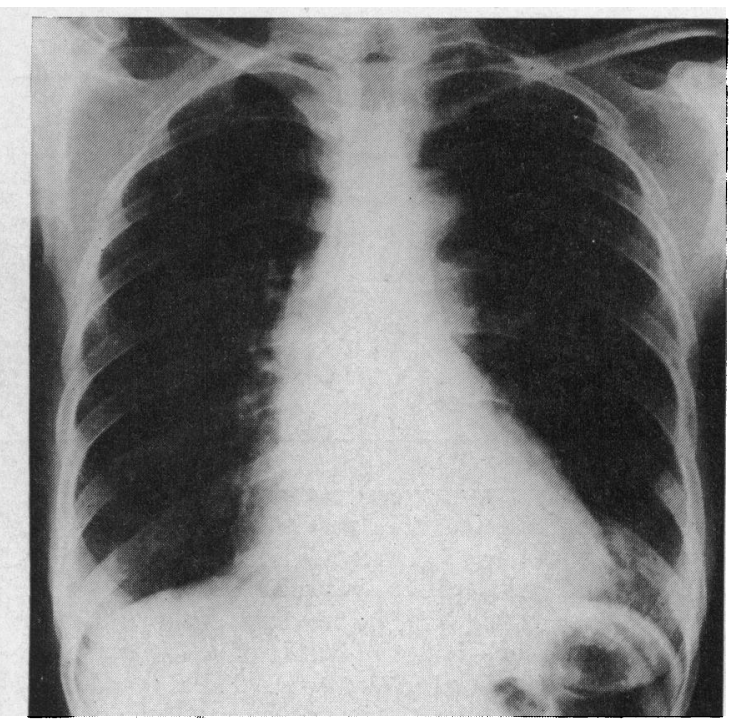

B

. (A) Before pericardiectomy. (B) After pericardiectomy.

serosanguineous fluid from which no tubercle bacilli were cultured. After injection of air no loculi were radiographically visible.

At pericardiectomy three weeks after admission, $\mathrm{Mr}$. P. R. Walbaum found the pericardium was about $5 \mathrm{~mm}$. thick and contained $600 \mathrm{ml}$. dark blood-stained fluid in its sac. The pericardium was removed from the anterior surface of the heart. The microscopical appearances were those of vascular granulation tissue with occasional peri-arteriolar infiltration by lymphocytes, and with fibrous tissue and fibrinoid material adjoining the lumen. These appearances suggested that the pericarditis was of long standing and secondary to a subacute arteritis of the type commonly seen in rheumatoid disease.

The post-operative course was uneventful apart from an episode of transient atrial fibrillation and cardiac failure which responded to digoxin and diuretics. One month after operation her serum gave a positive test for antinuclear factor. Fifteen months after operation the patient was well.

Case 3. A man of 54 years was admitted with a history of severe exertional dyspnœa for two years and with signs of congestive cardiac failure. His rheumatoid arthritis had been of acute onset at the age of 51, with pain and stiffness in both great toes, spreading to ankles, knees, neck, and shoulders. Three months later he had been admitted to another hospital on suspicion of having sustained a myocardial infarction, with a short-lived "searing" chest pain which was followed by a hot burning retrosternal discomfort lasting for some days. There was slight ankle œdema, and a coarse grating systolic pericardial friction rub was heard. A chest radiograph showed enlargement of the cardiac shadow accompanied by a small right-sided pleural effusion. The patient was treated with diuretics, and effusions in his elbows and knees were aspirated. He was subsequently treated as an out-patient with intraarticular injections of methylprednisolone acetate. During this period pericardial friction was repeatedly observed.

In the following year, at the age of 52, the patient was admitted under the care of Dr. J. J. R. Duthie with increasing dyspnœa. His hands, knees, and feet were painful and swollen. There was œdema, raised jugular venous pressure, and a right-sided pleural effusion. Pericardial friction was still present. The hæmoglobin was 99 per cent, ESR $55 \mathrm{~mm}$., and SSCT 1:1024. The test for ANF was negative. Radiographs of the hands showed early erosions in several joints; the feet showed osteoporosis only. Marked enlargement of the cardiac shadow was seen on the chest radiograph. The pleural effusion was aspirated and proved sterile. Direct examination and culture for Myco. tuberculosis was negative. Pleural biopsy showed fibrous thickening with a scanty infiltration by inflammatory cells. Both the pericarditis and the pleural reaction were considered to be visceral manifestations of rheumatoid disease. The patient was given salicylates, digoxin, and diuretics, but not until treatment with prednisolone was instituted was there a significant improvement. After four months in hospital he was discharged on a maintenance dose of prednisolone $12.5 \mathrm{mg}$. daily.

The patient continued to attend the Rheumatic Diseases Clinic. Tiny areas of necrosis appeared from time to time close to the finger-nails, and were thought to indicate the presence of an arteritis. The pericardial friction rub remained audible for a total of 18 months, and was last noted some 5 months after discharge from 
the ward. Two months later the patient suffered a further attack of acute chest pain which radiated to the jaw, with dyspncea. A QS complex was present in leads II, III, and aVF of the cardiogram, and T waves were inverted in leads V4 to V6 (Fig. 3). These changes were thought to indicate further myocardial infarction. Nine months after this he developed ankle œdema and breathlessness on exertion, and was readmitted to the Rheumatic Diseases Unit in congestive cardiac failure. There was moderate œdema and hepatic enlargement, and despite medical treatment the jugular venous pressure remained raised at about $17 \mathrm{~cm}$. The heart shadow was still enlarged, with a CTR of $190 / 300$ or 63 per cent (Fig. 4), but the heart sounds were normal and there was no significant pulsus paradoxus. At cardiac catheterization the right atrial mean and diastolic pressures were high, at 20 and $18 \mathrm{~mm} . \mathrm{Hg}$, respectively. There was a steep " $y$ " descent which was followed in the right ventricle by a high end-diastolic plateau 0 $18 \mathrm{~mm}$. $\mathrm{Hg}$, of the type seen in constrictive pericarditis. Right heart angiography demonstrated an abnormally wide gap between the cavity of the right atrium and the border of the cardiac shadow, but no fluid was withdrawn when aspiration from the pericardial sac was attempted.

Mr. P. R. Walbaum carried out pericardiectomy and found a patchily adherent visceral and parietal pericardium. Only a small amount of turbid liquid was present. After decortication the action of both ventricles was much more vigorous. Histological examination of the fused epicardium and pericardium showed laminated collagenous connective tissue. There was no true vasculitis.

Following operation the venous pressure was lower, there was a little sacral œdema but no ankle œdema, and the liver was no longer palpable. The post-operative period was complicated by severe herpes zoster and postherpetic neuralgia. Cardiac failure recurred, and three months after operation the jugular venous pressure was as high as it had been before operation.

The patient suffered recurrent attacks of angina pectoris that frequently appeared to be triggered by the post-herpetic neuralgia. Six months after operation he had severe chest pain with hypotensive shock. The serum glutamic oxalacetic transaminase level rose from 15 to 178 units (Sigma-Frankel) in the first 24 hours. The cardiogram was not significantly changed. Following this episode the chest pain did not recur even during attacks of post-herpetic neuralgia, but cardiac failure was difficult to control. His condition deteriorated and he became more breathless. Nine months after operation he was readmitted to hospital in severe congestive failure and with hepatic and renal failure, and died three weeks later.

Findings at Necropsy. Bronchopneumonic areas were present in the upper lobes of both lungs, and elsewhere the alveolar septa were thickened and congested, with hæmosiderin-laden macrophages in the alveolar spaces, indicating long-standing left ventricular failure. The right pleural sac contained about 2 litres of strawcoloured liquid, and the parietal and visceral pleural

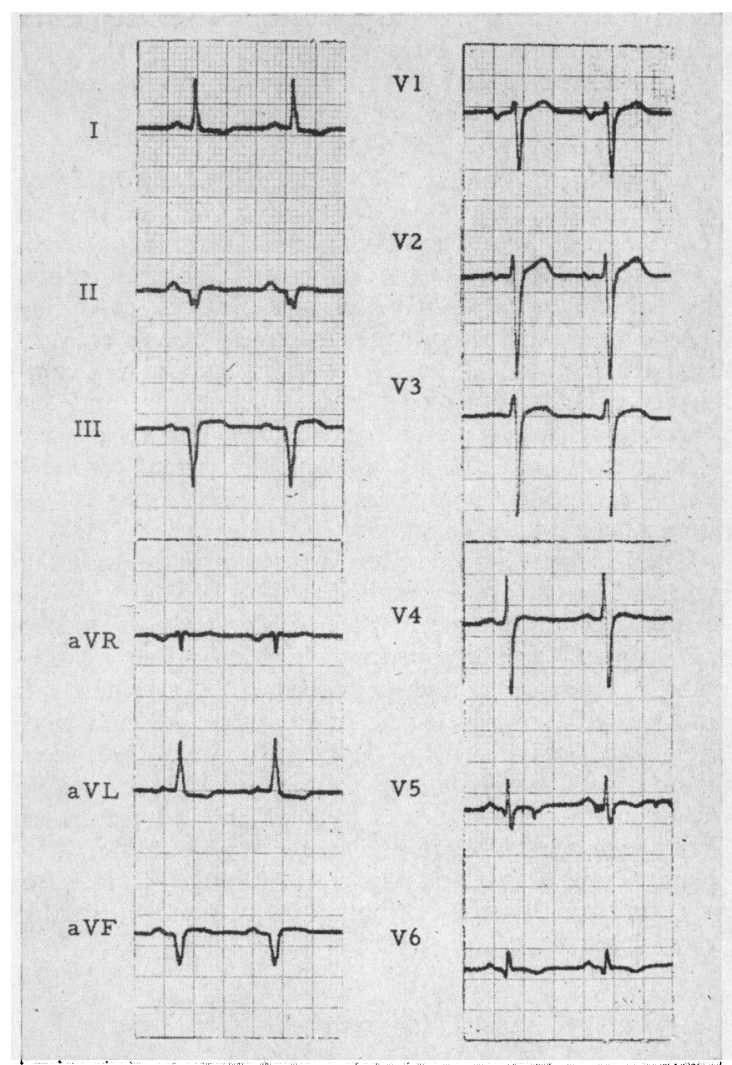

FIG. 3 (Case 3).-Electrocardiogram before pericardiectomy. (See text.)

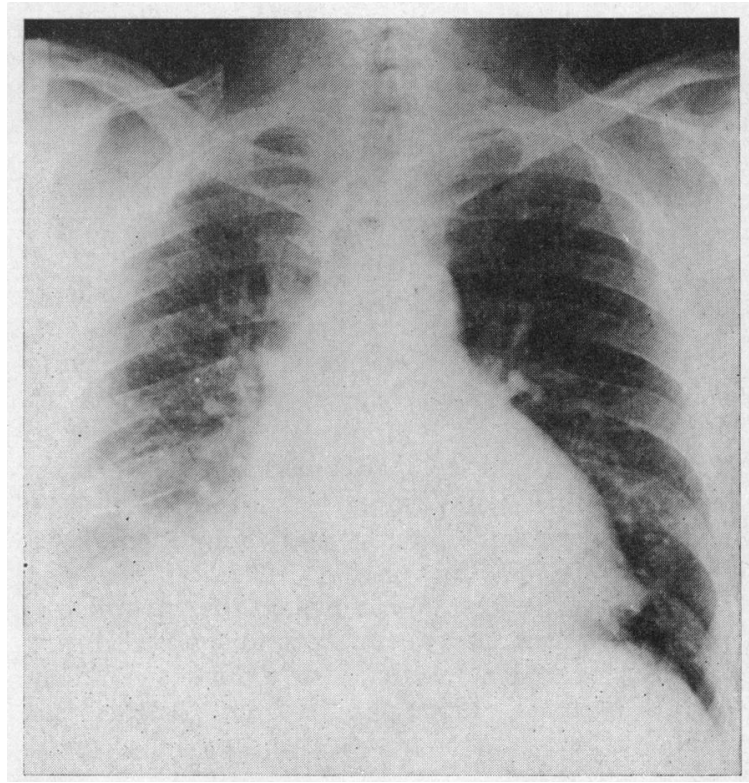

FIG. 4 (Case 3).-Chest radiograph before pericardiectomy. 
layers were thickened and fibrosed. The left pleural sac was obliterated by fibrous adhesions.

The heart weighed $550 \mathrm{~g}$., but some of this weight included fibrous tissues overlying the epicardium as a result of the previous pericardiectomy. The ventricular muscle was pale and flabby, and areas of fibrosis were present in the anterior and posterior walls of the left ventricle and in the interventricular septum. Microscopical examination of the left ventricular myocardium showed extensive fibrosis, in some places extending from endocardial to epicardial surfaces, plainly areas of healed infarction. The left coronary artery was completely occluded by an atheromatous plaque, and the circumflex and anterior descending branches were greatly narrowed by atheroma. The right coronary artery was moderately narrowed. There was no microscopical evidence of an arteritis.

The liver was a pale yellowish colour, with a nodular wrinkled surface, and weighed $1400 \mathrm{~g}$. Microscopical examination revealed marked congestion associated with fibrosis around central veins, indicating a longstanding chronic venous congestion. The spleen was firm and enlarged, weighing $350 \mathrm{~g}$. The adrenals were small and atrophic. No significant abnormalities were found in other organs, and in particular there was no gross or microscopical evidence of any arteritis. An interphalangeal joint of one finger was examined histologically, and the existence of rheumatoid arthritis was confirmed by the finding of pannus and erosion of articular cartilage.

\section{Discussion}

Pericarditis in rheumatoid disease was described as a necropsy finding by Charcot in 1881 . It has been known as a complication of juvenile rheumatoid arthritis since Still's classic description of 1897, but was not thought of as a feature of the adult disease for many years. Attention was drawn to the cardiac manifestations of rheumatoid disease by Baggenstoss and Rosenberg in 1941. Adhesive, obliterative, or fibrinous pericarditis has been the type most commonly described in necropsy series (Fingerman and Andrus, 1943; Young and Schwedel, 1944; Graef, Hickey, and Altmann, 1949; Bywaters, 1950; Sokoloff, 1953; Levin et al., 1955; Sinclair and Cruickshank, 1956; Cruickshank, 1958; Goehrs, Baggenstoss, and Slocumb, 1960; Cathcart and Spodick, 1962; Lebowitz, 1963). The reported incidence has varied widely, between 11 per cent (Fingerman and Andrus, 1943) and 50 per cent (Young and Schwedel, 1944; Graef et al., 1949; Egelius et al., 1955).

Necropsy studies have indicated that rheumatoid pericarditis frequently remains undiagnosed during life (Young and Schwedel, 1944; Clark and Bauer, 1948; Bywaters, 1950; Sinclair and Cruickshank, 1956). Even acute pericarditis may be undetected (Graef et al., 1949). These findings have been supported by the low incidence of clinically detectable pericarditis in patients with rheumatoid disease (Rogen, 1947; Fischmann and Gwynne, 1948; Rosenberg et al., 1950; Egelius et al., 1955; Cathcart and Spodick, 1962; Lebowitz, 1963).

Acute rheumatoid pericarditis is not commonly reported in adults; Cathcart and Spodick (1962) describe 5 in a series of 254 patients with rheumatoid arthritis, while in most clinical series no examples of pericarditis occur. The acute pericarditis may antedate the appearance of overt rheumatoid arthritis (Gimlette, 1959; Connolly and Burchell, 1961; Grossman et al., 1962). Effusions occurring with acute pericarditis have not been large enough to interfere with cardiac function (Thomas and Morgan, 1956; Connolly and Burchell, 1961).

An effusion may accompany chronic rheumatoid pericarditis, but in most reported cases there has been no adverse effect on cardiac function (Ellman and Ball, 1948; Gruenwald, 1948; Ogryzlo, 1953; Goehrs et al., 1960). Young and Schwedel (1944) found one pericardial effusion of $400 \mathrm{ml}$. in a series of 38 necropsies, but ascribed it to congestive failure. The present authors are aware of only two reports of cardiac compression arising from chronic rheumatoid pericardial effusion. Handforth and Woodbury (1959) described a girl of 16 years with rheumatoid arthritis of three years' duration who developed a bloody pericardial effusion and whose death was due to cardiac tamponade. At necropsy on another patient who suffered from severe and prolonged rheumatoid arthritis the pericardial sac contained over $350 \mathrm{ml}$. of bloody fluid "under so much tension that it appeared to have caused cardiac tamponade" (Bevans et al., 1954).

Rheumatoid disease has not been apparent in most published series of constrictive pericarditis, although Gimlette (1959) considered it a possible ætiological factor in five of 62 such patients. Deterling and Humphreys (1955), describing 30 patients with chronic constrictive pericarditis, and Wood (1961), in a series of 40 similar patients, do not mention rheumatoid disease in any. Wilkinson (1962) drew attention to the clinical manifestations of rheumatoid pericarditis, but pointed out that in most cases it appeared not to be harmful. While this applies to a majority of cases, there is no doubt that the patients described by McMurray, Cayer, and Cornatzer (1951), Healey and Mozen (1957), Keith (1962), Glyn and Pratt-Johnson (1963), Kerr-Taylor (1963), Szatkowski and Inoue (1963), and Tubbs, Slade, and Turner-Warwick (1964) all benefited from pericardiectomy.

Rheumatoid pericarditis is commonly accompanied by other cardiac lesions. Sinclair and 
TABLE II

EVIDENCE OF RHEUMATOID ARTHRITIS IN THE THREE CASES OF PERICARDITIS

\begin{tabular}{|c|c|c|c|c|c|c|c|c|c|c|c|c|c|c|c|}
\hline \multicolumn{3}{|c|}{$\begin{array}{l}\text { Case No., sex, and } \\
\text { age }\end{array}$} & \multicolumn{8}{|c|}{$\begin{array}{l}\text { Rheumatoid arthritis } \\
\text { criteria` }\end{array}$} & LE cells & $\begin{array}{c}\text { Acid-fast } \\
\text { bacilli }\end{array}$ & ESR & CTR & Other findings \\
\hline $\begin{array}{l}1 \\
2 \\
3\end{array}$ & $\begin{array}{l}\mathrm{M} \\
\mathrm{F} \\
\mathrm{M}\end{array}$ & $\begin{array}{l}49 \\
51 \\
54\end{array}$ & $\begin{array}{l}+ \\
+ \\
+\end{array}$ & $\begin{array}{l}+ \\
+ \\
+\end{array}$ & $\begin{array}{l}+ \\
+ \\
+\end{array}$ & $\begin{array}{l}+ \\
+ \\
+\end{array}$ & $\begin{array}{l}+ \\
+\end{array}$ & + & $\begin{array}{l}+ \\
+ \\
+\end{array}$ & $\begin{array}{l}+ \\
+ \\
+\end{array}$ & $\begin{array}{l}\text {-ve } \times 4 \\
\text {-ve } \times 5 \\
\text { - ve }\end{array}$ & $\bar{z}$ & $\begin{array}{l}43 \\
50 \\
55\end{array}$ & $\begin{array}{l}180 / 300 \\
240 / 270 \\
190 / 300\end{array}$ & $\begin{array}{l}\text { Bilateral pleural effusions } \\
\text { Rheumatic valvular disease } \\
\text { Right pleural effusion }\end{array}$ \\
\hline
\end{tabular}

* Key to criteria of American Rheumatism Association (1959): 1: joint stiffness (morning stiffness); 2: pain on movement or tenderness in at least one joint; 3 : swelling in at least one joint; 4: swelling in other joints within 3 months; $5:$ bilateral symmetrical joint swelling; 6: subcutaneous nodules; 7: radiographic changes of rheumatoid arthritis; 8: positive serology (rheumatoid factor). $\mathrm{CTR}=$ Cardiothoracic ratio.

Cruickshank (1956) recorded 16 cases of rheumatoid arthritis with visceral involvement; 13 had cardiac lesions and 7 of these also had pericarditis, but none had pericarditis alone. Myocardial damage may be a factor contributing to cardiac failure. Gimlette (1959) suggested that myocardial involvement may be more severe in rheumatoid disease than in other conditions producing constrictive pericarditis. Graef et al. (1949) recorded 7 instances of active interstitial myocarditis in a series of 66 necropsies on patients with rheumatoid arthritis, and two cases in which lesions like those of polyarteritis nodosa were seen in the coronary arteries. Acute diffuse myocarditis was reported in 2 of 61 cases of rheumatoid arthritis examined at necropsy (Fingerman and Andrus, 1943).

The common feature of the three cases presented here was their history of chronic rheumatoid arthritis with the insidious onset of congestive cardiac failure. In all cases there was good evidence of rheumatoid arthritis according to the criteria of the American Rheumatism Association (1959) (see Table II). In no case was there positive evidence of tuberculosis. No LE cells were found, though antinuclear factor developed in Case 2. A proportion of rheumatoid sera contain $\mathrm{ANF}$, and a positive test for ANF is not in itself diagnostic of systemic lupus erythematosus (Weir, Holborow, and Johnson, 1961). This patient had a chronic deforming arthritis with no rash, and a normal blood pressure and renal function. She also had rheumatic valvular disease, but it is unlikely that such a gross and chronic pericardial effusion was of rheumatic origin.

The third patient differed in his history of acute chest pain and in having an adhesive, rather than effusive, pericarditis, while his improvement after pericardiectomy was only temporary. During life it was difficult to establish whether his attacks of chest pain were due to acute pericarditis or to myocardial ischæmia. There was evidence at necropsy of gross coronary atheroma with occlusion of the left coronary artery and extensive healed infarction. Ischæmic heart disease was undoubtedly the cause of the recurrence of congestive failure after pericardiectomy. It seems likely, however, that the pericarditis and pleurisy were manifestations of rheumatoid disease, and it should be stressed that pericardial friction was audible for 18 months.

Gimlette's view that rheumatoid subjects may have more myocardial involvement than other patients with constrictive pericarditis, and the difficulty in the present case in determining whether the congestive failure was due to compression or to ischæmic heart disease, suggest that the risk of a poor operative result even in carefully selected cases must be appreciable.

It seems probable that the clinical features of pericarditis are often overlooked in rheumatoid disease, but it should be remembered that cardiac lesions may be present in any patient with rheumatoid arthritis. Our experience with 3 patients developing chronic cardiac decompensation on a basis of rheumatoid disease illustrates the good results that surgery may sometimes have in this condition, and also the difficulties that may be faced in making a final diagnosis.

The lesson to be learned is that in all cases of rheumatoid arthritis the clinician should ask himself whether there is evidence of pericarditis, and in all cases of pericarditis whether there is evidence of rheumatoid arthritis.

\section{SUMMARY}

Three patients with rheumatoid arthritis and cardiac failure are described. In two the failure resulted from rheumatoid pericarditis, and was abolished by pericardiectomy. The third patient had pericarditis with some features of constriction, but pericardiectomy gave only temporary improvement, and the necropsy showed severe coronary 
arterial disease which was probably a major factor contributing to the cardiac failure. It is suggested that rheumatoid disease may be a more common cause of harmful chronic pericarditis than has hitherto been recognized.

We are grateful to Dr. George Summers for referring Cases 1 and 2, to Dr. J. J. R. Duthie for allowing us to study Case 3, to Mr. P. R. Walbaum and Mr. R. J. M. McCormack for their operative findings, and to Dr. D. L. Gardner for the histological examinations. We are also indebted to Dr. J. N. Webb for the necropsy report on Case 3. One of the authors (R.E.H.P.) was supported by a grant from the Arthritis and Rheumatism Council.

\section{REFERENCES}

American Rheumatism Association (1959). Primer on the rheumatic diseases, Part 1. F. Amer. med. Ass., 171, 1205.

Baggenstoss, A. H., and Rosenberg, E. F. (1941). Cardiac lesions associated with chronic infectious arthritis. Arch. intern. Med., 67, 241.

Bevans, M., Nadell, J., Demartini, F., and Ragan, C. (1954). The systemic lesions of malignant rheumatoid arthritis. Amer. F. Med., 16, 197.

Bywaters, E. G. L. (1950). The relation between heart and joint disease including "rheumatoid heart disease" and chronic post-rheumatic arthritis. (Type-Jaccoud). Brit. Heart f., 12, 101.

Cathcart, E. S., and Spodick, D. H. (1962). Rheumatoid heart disease. New Engl. F. Med., 266, 959.

Charcot, J. M. (1881). Clinical Lectures on Senile and Chronic Diseases, translated by W. S. Tuke, pp. 172-175. The New Sydenham Society, Vol. 95, London.

Clark, W. S., and Bauer, W. (1948). Cardiac changes in rheumatoid arthritis. Ann. rheum. Dis., 7, 39.

Connolly, D. C., and Burchell, H. B. (1961). Pericarditis: a ten year survey. Amer. F. Cardiol., 7, 7.

Cruickshank, B. (1958). Heart lesions in rheumatoid disease. f. Path. Bact., 76, 223.

Deterling, R. A., and Humphreys, G. H. (1955). Factors in the etiology of constrictive pericarditis. Circulation, $12,30$.

Egelius, N., Göhle, O., Jonsson, E., and Wahlgren, F. (1955). Cardiac changes in rheumatoid arthritis. Ann. rheum. Dis., 14, 11.

Ellman, P., and Ball, R. E. (1948). "Rheumatoid disease" with joint and pulmonary manifestations. Brit. med. F., $2,816$.

Fingerman, D. L., and Andrus, F. C. (1943). Visceral lesions associated with rheumatoid arthritis. Ann. rheum. Dis., 3, 168.

Fischmann, E. J., and Gwynne, F. J. (1948). The heart in rheumatoid arthritis. Brit. Heart f., 10, 125.

Gimlette, T. M. D. (1959). Constrictive pericarditis. Brit. Heart $\mathcal{F}, 21,9$.

Glyn, J. H., and Pratt-Johnson, J. H. (1963). Rheumatoid pericarditis. Brit. med.F., 1, 262.

Goehrs, H. R., Baggenstoss, A. H., and Slocumb, C. H. (1960). Cardiac lesions in rheumatoid arthritis. Arthr. and Rheum., 3, 298.
Graef, I., Hickey, D. V., and Altmann, V. (1949). Cardiac lesions in rheumatoid arthritis. Amer. Heart f., 37, 635.

Grossman, L. A., Kaplan, H. J., Ownby, F. D., and Grossman, M. (1962). Acute pericarditis with subsequent clinical rheumatoid arthritis. Arch. intern. Med., 109, 665.

Gruenwald, P. (1948). Visceral lesions in a case of rheumatoid arthritis. Arch. Path., 46, 59.

Handforth, C. P., and Woodbury, J. F. L. (1959). Cardiovascular manifestations of rheumatoid arthritis. Canad. med. Ass. F., 80, 86.

Healey, F. H., and Mozen, H. E. (1957). Chronic cardiac compression (constrictive pericarditis) and rheumatoid arthritis; a case report. Ohio St. med. F., 53, 1146.

Keith, T. A. (1962). Chronic constrictive pericarditis in association with rheumatoid disease. Circulation, 25, 477.

Kerr-Taylor, H. (1963). Pericarditis in a case of rheumatoid arthritis. Rheumatism, 19, 94.

Lebowitz, W. B. (1963). The heart in rheumatoid arthritis. A clinical and pathological study of sixty-two cases. Ann. intern. Med., 58, 102.

Lietman, P. S., and Bywaters, E. G. (1963). Pericarditis in juvenile rheumatoid arthritis. Pediatrics, 32, 855.

Levin, M. H., Kaplan, L., Marcus, S., Weinberger, H. J., and Patterson, J., Jr. (1955). Heart in rheumatoid arthritis: a clinical-pathologic correlation of 43 autopsied patients. Ann. rheum. Dis., 14, 430.

McMurray, C., Cayer, D., and Cornatzer, W. E. (1951). Chronic adhesive pericarditis due to the rheumatic state, associated with liver damage, serous effusions, and pigmentation. Gastroenterology, 17, 294.

Ogryzlo, M. A. (1953). Diffuse systemic rheumatoid disease. Ann. rheum. Dis., 12, 323.

Partridge, R. E. H., and Duthie, J. J. R. (1963). Rheumatoid pericarditis. Brit. med.f., 1,611 .

Rogen, A. S. (1947). The heart in rheumatoid arthritis. Brit. med.F., 1, 87.

Rosenberg, E. F., Bishop, L. F., Weintraub, H. J., and Hench, P. S. (1950). Cardiac lesions in rheumatoid arthritis. Arch. intern. Med., 85, 751.

Sinclair, R. J. G., and Cruickshank, B. (1956). A clinical and pathological study of sixteen cases of rheumatoid arthritis with extensive visceral involvement. Quart. F. Med., n.s. 25, 313.

Sokoloff, L. (1953). The heart in rheumatoid arthritis. Amer. Heart f., 45, 635.

Still, G. F. (1897). On a form of chronic joint disease in children. Med.-chir. Trans., 80, 47.

Szatkowski, J., and Inoue, T. (1963). Cholesterol pericarditis. An unusual case of probable tubercular origin in a patient with rheumatoid arthritis. Amer. $\mathcal{F}$. Cardiol., 12, 730.

Thomas, A. E., and Morgan, W. K. C. (1956). Pericarditis complicating rheumatoid arthritis. Ann. rheum. Dis., $15,176$.

Tubbs, O. S., Slade, P. R. H., and Turner-Warwick, $M$. (1964). Constrietive pericarditis in association with rheumatoid arthritis. Thorax, 19, 555 .

Weir, D. M., Holborow, E. J., and Johnson, G. D. (1961). A clinical study of serum antinuclear factor. Brit. med.f., $1,933$.

Wilkinson, M. (1962). Rheumatoid pericarditis: a report of four cases. Brit. med.F., 2, 1723.

Wood, P. (1961). Chronic constrictive pericarditis. Amer. F. Cardiol., 7, 48.

Young, D., and Schwedel, J. B. (1944). The heart in rheumatoid arthritis. Amer. Heart f., 28, 1. 